\title{
Picking Up the Pieces: Library Processes and the Theft of Rare Materials
}

\begin{abstract}
In October 2018, Brigham Young University's Harold B. Lee Library experienced thefts from its general circulating collection and L. Tom Perry Special Collections. This article explores the literature on theft in special collections and libraries in general, reviews the events that occurred as a case study in dealing with theft, and concludes with some thoughts on how institutions can avoid purchasing stolen materials. We also include our analysis of one of the stolen books to explain how we knew it belonged to the university and a sample theft reporting checklist.
\end{abstract}

\section{Introduction}

Evaluating library vulnerabilities following acts of theft and vandalism is an essential aspect of librarianship and archival management, as theft is a constant threat for all institutions and something libraries open to the public experience frequently. ${ }^{1}$ While everyday theft is likely not worth an all-hands-on-deck announcement, the theft of especially valuable materials ought to be recognized as both a warning and an opportunity. As the recently approved ACRL/RBMS Guidelines Regarding Security and Theft in Special Collections suggest, when materials from particular areas of a library or archives' collections are stolen, they may be targeted again in the future. ${ }^{2}$

This article will provide a review of the professional literature regarding theft of library and special collections materials. The authors will then describe in detail as a case study a recent theft that occurred at Brigham Young University's Harold B. Lee Library, which ultimately led to prosecution and the return of many of the items, as well as actions that the library's L. Tom Perry Special Collections has taken to

1. Among more recent studies of the prevalence of theft in special collections, a 2013 study found that 22 of 78 responding special collections had experienced a theft. See Michael Mounce and Patricia Mounce, "An Investigation of Special Collections Library Theft," Library and Archival Security 25, no. 2 (2012), 105-06, https:// doi.org/10.1080/01960075.2013.765784.

2. Association of College and Research Libraries and Rare Books and Manuscripts Association, "ACRL/RBMS Guidelines Regarding Security and Theft in Special Collections," www.ala.org/acrl/standards/security_theft [accessed 28 January 2020].

(C) 2020 by Gregory Seppi and Dainan Skeem (CC BY-NC [https://creativecommons.org/licenses/ by-nc/4.0/]). 
prevent similar theft in the future. Last, there will be discussion concerning ways in which libraries and special collections can prevent the theft of valuable materials and how, as institutions, we can avoid purchasing stolen materials that get added to our own collections. The intent is that, with continued discussion on this topic, we will raise awareness of the threat of theft from our collections so that necessary measures, as many as are feasible, will be taken to prevent it.

\section{Literature Review}

Theft is a significant problem for libraries and archives worldwide. ${ }^{3}$ All libraries face inventory control issues, but the outright theft of valuable or rare books and manuscripts is a long-term compound-interest problem with no easy answers. ${ }^{4}$ While all institutions acknowledge the threat of thefts, scholarship and professional literature on the topic is less developed than one might expect. This is not to say that there is any paucity of articles and books on thefts; scholarship on the topic is wide-reaching, especially with regard to articles that raise awareness of the issue of theft and those that cover prevention and prosecution, but few case studies document the aftermath of a major theft. Catching a book thief once theft is recognized to have happened adds layers of difficulty to the problem, since book thieves are rarely prosecuted with the same vigor as other areas of crime. Prosecuting so-called "victimless crimes" (though theft of rare books and manuscripts is far from victimless) is hardly as sexy to the public as locking up drug dealers or armed robbery suspects. ${ }^{5}$

3. Recent scholarship on the prevalence of theft at different types of libraries includes Muhammad Yousuf Ali, "Library Book Theft and Audits in University Libraries of Pakistan," Journal of Library Administration 57, no. 1 (December 2016): 87-98, https:/ / doi.org/10.1080/01930826.2016.1251252; Peter E. Hanff, "The Story of the Berkeley Library Theft," College \& Research Libraries News 45, no. 6 (1984): 284-88, https://crln.acrl.org/index.php/crlnews/article/view/22248/28341; Innocent Sunday Idakwo, "Theft and Mutilation on the Use of Library Resources in Nigerian Academic Libraries," Library Philosophy and Practice (August 2019): 1-6, https://search.proquest.com/docview/22997641 78? accountid=4488; Li Xiaoning, "On the Internal Theft Phenomenon and the Security of Library Collections," Library Journal of Shandong (April 2017), http:/ / en.cnki.com.cn/Article_en/CJFDTotalSDTG201704012.htm; Susan M. Allen, "Theft in Libraries or Archives," College \& Research Libraries News 51, no. 10 (October 1990): 939-44, https: / / doi.org/10.5860/crln.51.10.939. A full-day seminar on global book theft held at the British Library in 2015 noted that the "theft of and illicit trafficking in rare books, maps and manuscripts looted from sovereign and other libraries and similar repositories around the world is a global problem that threatens the preservation of the recorded history of mankind": https:/ / www.bl.uk/ events/the-written-heritage-of-mankind-in-peril [accessed 4 February 2020].

4. A Council on Library and Information Resources report in 2000 noted, "Although it may be evident that libraries cannot perform mission work without having the resources to ensure that collections are accessible and secure over time, it is not always evident which investments in collection development, preservation, and security will best serve the collections at a given time." Laura Price and Abby Smith, Managing Cultural Assets from a Business Perspective (Washington, DC: Council on Library and Information Resources in Cooperation with the Library of Congress, March 2000), 1-2, https:/ / clir. wordpress.clir.org/wp-content/uploads/sites/6/pub90.pdf [accessed 10 February 2020].

5. Susan M. Allen, "Preventing Theft in Academic Libraries and Special Collections," Library and Archival Security 14, no. 1 (1997): 37. 
The professional literature related to theft and security of rare books and manuscripts includes both practical and theoretical responses. Special Collections and archives have been recognized as being especially vulnerable to thefts since managing the handling of physical objects is part of their purpose. ${ }^{6} \mathrm{How}$ an institution chooses to respond to theft can provide value to other libraries and organizations. For example, after experiencing high-profile thefts, the National Archives and Records Administration organized a Holdings Protection Team in 2010. One author who attended a seminar on security hosted by NARA noted that this Holdings Protection Team had some important strengths from the outset, including:

- Team composition, with at least one member coming from a traditional federal government law enforcement background;

- Comprehensive scope, its ability to work across all of the sites managed by NARA to implement changes;

- $\quad$ Flexibility to work with all staff. ${ }^{7}$

Other security improvements recommended in the literature include more roaming by employees and increased patron interaction to make sure proper supervision is maintained. ${ }^{8}$ Increasing the level of manuscript collection processing can ensure that materials are properly accounted for. ${ }^{9}$ While this conflicts to some degree with MPLP principles common in today's archival processing areas, the security tradeoff for collections known to have valuable materials within them may justify a slightly longer processing time (such as penciling item counts onto folders). Ironically, however, detailed online inventories can act as a kind of "shopping list" for a thief, but how security and access are balanced is something every institution must determine on its own, in consultation with its community and leaders. ${ }^{10}$ While access should not always outweigh security, both must be considered.

There have been many physical barriers implemented in libraries and special collections to deter theft. Examples include barcoding collections, weighing materials before and after patron use, adding RFID tags to valuable items, restricting access to storage areas, creating detailed inventories of collections, and installing cameras

6. Michael Mounce and Patricia Mounce, "An Investigation of Special Collections Library Theft," Library \& Archival Security 25, no. 2 (2012): 108-11, https: / / doi.org/10.1080/01960075.2013.765784.

7. Anna Griffith, "Learning from the Holdings Protection Team at the National Archives and Records Administration (NARA), USA,” Australian Library Journal 62, no. 2 (July 2013): 148-49, https:/ / doi. org/10.1080/00049670.2013.805457 [accessed 10 February 2020].

8. Brian W. Rossmann, "Stolen Documents," Dttp: Documents to the People 36, no. 1 (Spring 2008): 6.

9. Todd Samuelson, Laura Sare, and Catherine Coker, "Unusual Suspects: The Case of Insider Theft in Research Libraries and Special Collections," College \& Research Libraries 73, no. 6 (November 2012): 557.

10. Ross Griffiths and Andrew Krol, "Insider Theft: Reviews and Recommendations from the Archive and Library Professional Literature," Library \& Archival Security 22, no. 1 (2009): 10. 
in staff areas and research rooms. ${ }^{11}$ One author noted, "[a]s effective as such methods might be, they are often not practical, little used, or not employed properly. They are expensive, time consuming, and require more staff than most rare book and manuscript repositories could ever hope to muster." ${ }^{12}$ He adds another option to the physical barriers list, which is weighing materials at different stages of the acquisition and reference cycles, providing a base from which materials can always be reweighed upon conclusion of their use.

Library security researchers have also proposed fully prosecuting those who damage the cultural heritage of libraries and archives to discourage the theft of rare books and manuscripts. As one author noted, "the most important lesson I have learned is that it is important to file police reports when significant collection thefts are identified, and not to treat thefts as just part of doing business." ${ }^{13}$ Encouraging law enforcement to take seriously the theft of library materials, especially rare archival materials, helps shift law enforcement priorities with the goal of deterring future thefts and perhaps increasing the possibility that the stolen materials are eventually recovered. Moreover, attempting to cover up thefts in a misguided attempt to save face or avoid embarrassment prevents an organization from making changes to improve security. It can also mask complicity from an organization's employees.

One important consideration in the literature on the theft of cultural objects is how such objects are acquired by institutions and collectors. Existing professional literature regarding the illicit sale and transport of cultural artifacts tends to focus on either the international trade in antiquities or on the repatriation and disposition of materials significant or even sacred to marginalized communities. ${ }^{14}$ Considerations related to stolen property focus on the ethics of receiving objects with special value to a particular community rather than avoiding the purchase of stolen goods. While the present article details thefts that occurred at Brigham Young University's library and covers responses to these events, it also includes a discussion of

\footnotetext{
11. For examples of various security practices, see Everett C. Wilkie, Jr., "Weighing Materials in Rare Books and Manuscript Libraries as a Security Measure against Theft and Vandalism," RBM: A Journal of Rare Books, Manuscripts, and Cultural Heritage 7, no. 2 (2006): 146. Numerous methods to deter insider theft are also discussed by Griffiths and Krol, "Insider Theft."

12. Wilkie, "Weighing Materials in Rare Books and Manuscript Libraries as a Security Measure against Theft and Vandalism," 146.

13. Rossmann, "Stolen Documents," 6.

14. Some examples of this kind of scholarship include Richard J. Cox et al., "A Different Kind of Archival Security: Three Cases," Library \& Archival Security 22, no. 1 (2009): 33-41; from a museum/ legal perspective, see also Linda F. Pinkerton, "Museums Can Do Better: Acquisitions Policies Concerning Stolen and Illegally Exported Art," Villanova Sports \& Entertainment Law Journal 5, no. 1 (1998): 59-72; Neil Brodie, "Stolen History: Looting and Illicit Trade, Museum," Museum International 55, no. 3/ 4 (2003): 10-22, https: / / doi.org/10.1111/j.1350-0775.2003.00432.x [accessed 11 February 2020]; Leila Amineddoleh, "Protecting Cultural Heritage by Strictly Scrutinizing Museum Acquisitions," Fordham Intellectual Property, Media \& Entertainment Law Journal 24, no. 3 (Spring 2014): 729-82.
} 
how librarians and archivists can avoid purchasing stolen materials. Following best practices in collection development principles is a basic aspect of archival, library, and museum science, but existing standards give much less consideration to the complexities of buying rare materials in the eBay era than they perhaps should. ${ }^{15}$

Ross Griffiths and Andrew Krol noted that insider theft (defined as theft by those with a position of trust and access to a collection) could cause "catastrophic damage to collections as well as to institutional morale and public image." 16 The authors noted that little analysis of the extent of insider or outsider theft had been carried out at that time, and their article provided a valuable synthesis of research in library and archival thefts by both insiders and outsiders.

\section{Case Study}

Due to a desire to protect witnesses and avoid impinging on any future legal action, the authors of this piece made the decision to anonymize much of the identifying information about witnesses and the book thief. Though the thief is easily identified from press reports, this article focuses on what the Harold B. Lee Library (HBLL) and L. Tom Perry Special Collections were doing previously to secure our valuable books and manuscripts, and what current professional standards recommend. We also discuss the hazards of purchasing rare books and manuscripts and suggest some practices that will help those involved in such purchases avoid buying stolen materials.

L. Tom Perry Special Collections (LTPSC) serves a student body of 33,000 undergraduates, hundreds of teaching faculty, and hundreds more family historians and researchers pursuing degrees from other institutions. We regularly send dozens of staff and faculty employees to local, regional, and national conferences. Our security policies at the time of the thefts were designed with SAA, ALA, and ACRL standards in mind. ${ }^{17}$ We also have access to student security staff and an on-site officer from the Brigham Young University Police Department. Our special collections reading room is monitored by at least one student employee at all times when a patron is present, and several cameras cover the room.

15. Many library book thieves sell their materials online. One recent case study noted that a particular book thief largely sold materials online; see Patrick Charles, "The Library Book Thief," AALL Spectrum 21, no. 3 (March/April 2017): 48. This was also the experience of Brigham Young University discussed below in this article. eBay and other online sales platforms give thieves relative anonymity and the ability to reach potential buyers far beyond their normal reach. See also Steve Twomey, "To Catch a Thief," Smithsonian Magazine (April 2008), https: / / www.smithsonianmag.com/history/to-catch-athief-1-31735490/ [accessed 11 February 2020].

16. Griffiths and Krol, "Insider Theft," 5-18.

17. See the Association of College and Research Libraries" policy document "ACRL/RBMS Guidelines Regarding Security and Theft in Special Collections" at www.ala.org/acrl/standards/security_theft. SAA adopted these same guidelines and has followed them since 1993 (see https:/ / www2. archivists.org/groups/standards-committee/acrlrbms-guidelines-regarding-security-and-theft-in-specialcollections). 
The thefts at BYU were carried out by a rare bookseller who used eBay and personal contacts to sell stolen materials. ${ }^{18}$ Although not a student at Brigham Young University, he became a Friend of the Harold B. Lee Library with circulation privileges in September 2018. On October 1 and October 4, 2018, the dealer checked out a number of items that he then sold to various Utah booksellers. These books were targeted for their general rarity on the market or because of association signatures in the books. We are not certain how particular books were chosen over others, but it seems likely that he used a combination of keyword searches of library books on Internet Archive, the Harold B. Lee Library catalog, and on-site browsing.

Once the books were checked out, the suspect removed the barcodes and checkout slips from each book. He then returned to the library with the removed barcodes and checkout slips and pasted them into other copies of the same or similar books after removing their barcodes and slips. The suspect then "returned" this second set of books to the library. Our systems thus marked the first set of books as returned. While student employees check in returned books, the suspect was able to avoid damaging the barcodes during the switch, meaning they were not flagged during the check-in process.

Additionally, the suspect visited L. Tom Perry Special Collections twice and viewed a number of rare late nineteenth-century photographs. During one visit, a security camera recorded him removing a photograph from a mylar sleeve, setting it on his lap, and pulling something out of his pocket, which he then placed in the mylar sleeve. L. Tom Perry Special Collections curator of photography Tom Wells identified the item removed as an original stereoview of Orrin Porter Rockwell, a popular and colorful nineteenth-century Mormon figure. ${ }^{19}$ The suspect replaced the original image with a well-made forgery. While not so finely crafted as to fool an expert in photography, it could pass muster to any nonexpert under a brief inspection. This had the effect of foiling an item count at the departmental reference desk from detecting the theft.

The suspect then approached various booksellers with the stolen books and photograph. A local rare book collector purchased the Porter Rockwell photograph and three books removed from BYU's collection: Poetical Writings of Orson F. Whitney

\footnotetext{
18. Nate Carlisle, “'The Next Mark Hofmann?' Some of the historic Mormon documents Utahn sold were stolen from universities, court papers say; others were just fakes," The Salt Lake Tribune (November 27, 2018), https://www.sltrib.com/religion/2018/11/28/next-mark-hofmann-some/ [accessed 14 February 2020].

19. The basic source for the life of Porter Rockwell (1813-1878) is Harold Schindler, Orrin Porter Rockwell: Man of God, Son of Thunder, 2nd ed. (Salt Lake City, UT: University of Utah Press, 1993). Rockwell memorabilia is highly prized by some Latter-day Saints who romanticize his career as a bodyguard for Joseph Smith and Brigham Young, or are intrigued by his potential ties to murders in Illinois, Missouri, and Utah.
} 
(1889), an 1850 New Testament, and The Life of David P. Kimball and Other Sketches (1918). Had the purchaser not decided to check with the Harold B. Lee Library to see if he had purchased items stolen from the library, we would not have noticed the missing books until our next full shelf read. Because the thief swapped barcodes, the system would have shown that we were missing the second set of books and not the copies the suspect took. As such, there would have been no reason for us to suspect he was involved; suspicion would have shifted to the last people to check out the books with the swapped barcodes.

Greg Seppi, curator of 19th \& 20th Century Mormon and Western Americana, was first brought into the case when the local collector returned the library's copy of Whitney's Poetical Writings and the Rockwell image to the head of library security, BYU police officer Sgt. Besendorfer. He asked Seppi to determine if the book belonged to BYU. We were quite fortunate that the book stolen was digitized in 2009. ${ }^{20}$ Though the suspect took steps to obscure the book's origins, the book purchased by the collector was the same book. When we began checking library records to determine if we were the book's rightful owners, no note suggesting the book had been deaccessioned was located. The library catalog reported seven copies in the general stacks, and when we did a shelf read, our Copy 3-the digitized book-was missing from the library shelves despite being available according to the library catalog. Moreover, the suspect was the last person to have checked out the book. A review of the suspect's checkout history confirmed that the book was sold to the local collector while the suspect had it checked out. Within a few days, another rare bookseller came forward and returned two other books to us which he had acquired from the local collector, who purchased them from the suspect-a rare 1850 New Testament and The Life of David P. Kimball and Other Sketches (1918).

The suspect targeted books in the HBLL's regular collection that had significant provenance to collectors of Mormon-related books. For example, Poetical Writings was likely taken because it came out of the library of Abraham O. Smoot, an important late nineteenth-century figure in the Church of Jesus Christ of Latter-day Saints, and was signed by noted early twentieth-century Church poet and apostle, Orson F. Whitney, on the second front free endsheet. ${ }^{21}$ While several points of comparison be-

20. The digitized book (the stolen copy) is available at https://archive.org/details/poeticalwritings00whit/page/n3/mode/2up [accessed 21 February 2020].

21. A brief biographical sketch of Smoot's life can be found at https://lib.byu.edu/collections/ mormon-missionary-diaries/about/diarists/abraham-owen-smoot/, though this lacks the crucial detail that Smoot was also one of a handful of early Mormon settlers in Utah who owned slaves. See Peggy Fletcher Stack, "Pioneer Benefactor's Ties to Slavery Raise Questions for BYU, Where a Building Bears His Name," Salt Lake Tribune (August 9, 2019), https: / www.sltrib.com/new/education/2019/08/09/ pioneer-benefactors-ties [accessed 21 February 2020]. Orson F. Whitney (1855-1931) was married to one of Smoot's daughters, Zina Beal Smoot (1859-1900). He was a noted Latter-day Saint leader, orator, and theologian in Utah. For further details on his life and legacy, see Dennis B. Horne, The Life of Orson F. Whitney: Historian, Poet, Apostle, as Recorded in His Daily Journals (Springville, UT: Cedar Fort, 2014). 
tween our Internet Archive copy of Poetical Writings and the book returned to us are listed below in appendix A, there are hundreds of similar points that could be used to identify the stolen book as the same copy we digitized in 2009. All books develop unique points of wear and tear or other markings over time, and these can be used to identify particular copies as long as those points are described in a catalog or database or visible on a digital image of the specific item, as they were in this case.

While we evaluated Whitney's Poetical Writings, L. Tom Perry Special Collections Head of Reference Services Gordon Daines and Curator of Photography Tom Wells worked with Sgt. Besendorfer to review footage of the suspect's visit to Special Collections. They determined that he had stolen the Porter Rockwell image that was returned to us, as described above. The suspect was asked to meet with Sgt. Besendorfer at the BYU Police Department, and there confessed to having taken the copy of Poetical Writings. He stated that he switched its barcode to another book, which he then turned in to the library. Based on this information and additional evidence related to an attempted theft at Utah State University, Detective Jeff Long from the BYU Police Department and Sgt. Besendorfer received a warrant to search the suspect's home and recovered four additional Harold B. Lee Library books and a page torn out of a book that had been signed by former Church of Jesus Christ of Latter-day Saints President Joseph Fielding Smith. ${ }^{22}$ Seppi examined our six remaining copies of Whitney's Poetical Writings and confirmed that the thief had removed the barcode from copy 4 that was still in the library and pasted the barcode from his stolen copy 3 into copy 4 .

Life of David P. Kimball was likely stolen because the first free endsheet is inscribed "To Apostle James E Talmage With best wishes from David P Kimball's Sons April 6, 1918." ${ }^{\prime 23}$ We verified that the suspect had again performed the barcode switch with another copy from our collection. Though we learned the suspect sold the 1850 New Testament to the local collector, the suspect apparently did not have time or perhaps decided not to switch its barcode to another copy of the Bible or New Testament, though he did remove it and any other identifying marks before

22. Joseph Fielding Smith (1876-1972) presided over the Church of Jesus Christ of Latter-day Saints from 1970 to 1972 . He was well known for writing apologetic works on the history of the Church and its members and spent decades as the Church Historian, responsible for preserving the Church's history and setting access policies for public use of the Church's vast archives. He represented a link between the Church and its founder, Joseph Smith, as he was the grandson of Joseph Smith's brother Hyrum. Francis M. Gibbons, Joseph Fielding Smith: Gospel Scholar, Prophet of God (Salt Lake City, UT: Deseret Book, 1992).

23. James E. Talmage (1862-1933) was a noted Latter-day Saint leader as well as a prominent chemist and geologist. He also authored many popular books related to the history of the Church of Jesus Christ of Latter-day Saints. He remains popular among Latter-day Saints today. A basic biography is John R. Talmage, The Talmage Story (Salt Lake City, UT: Bookcraft, 1972). David P. Kimball (1839-1883) is best remembered for his valiant actions in bringing members of a Church handcart company across the Sweetwater River in 1856 despite extreme winter conditions. See Chad M. Orton, "The Martin Handcart Company at the Sweetwater," BYU Studies 45, no. 3 (2006): 8. 
selling it. Sgt. Besendorfer and Seppi looked at security camera footage from the day the suspect checked out the New Testament. We watched him go to the circulation desk with the book and had it checked out to him. Unfortunately, camera footage from the suspect's earlier checkouts was auto-deleted after 30 days, before all of the relevant information was understood. Further review of footage to see if we had recorded him returning the books with tampered barcodes was not successful. Books can be returned from many places in the library, so too many possible return points existed, many not covered by cameras.

Each of the books recovered from the collector and bookseller was a book checked out by the suspect. We verified that each book recovered was listed as available in our library catalog but was not present on the shelf and that each had its barcodes moved to another book. With only two exceptions, each book returned to us had its barcode removed and placed on a different copy of the same title in the HBLL's Religion and Family History Library. The two exceptions were the 1850 New Testament and The Autobiography of Christopher Layton. Neither book had a second copy for the suspect to tamper with, so he switched the barcode from Autobiography to a much later family history titled Christopher Layton. We currently have no evidence that the 1850 New Testament had its barcode placed in another book.

One other exception is a book checked out by the suspect that he did not steal. All of our copies of that book, including one signed by the author, were present and accounted for and did not appear to have had barcodes modified. Finally, we were unable to identify the book the suspect took the Joseph F. Smith Jr. signature from, but the library accession number on the page clearly indicated that it was from our collection. ${ }^{24}$

Seppi met with the HBLL Circulation team and transferred the recovered books to police evidence at the BYU Police Department. Unfortunately, three additional books remained missing from the HBLL's collection. We verified that the suspect had checked out these books and that their barcodes had been moved to other copies of the same works. We were able to recover these additional missing books in February 2020 due to the efforts of local booksellers to return them to us.

\section{The 2019 ACRL/RBMS Security Standards}

In the following section, we compare the 2019 ACRL/RBMS Security Standards document to our practices prior to the theft of the Porter Orrin Rockwell photograph. ${ }^{25}$ This document was an excellent source for identifying shortcoming in

24. Unfortunately, the library had discarded some accession number records for books that had been in the library for many years, so we were unable to use it to match the page to a book.

25. "ACRL/RBMS Guidelines Regarding Security and Theft in Special Collections," ALA.org, Association of College and Research Libraries, 2009, revised 2019, www.ala.org/acrl/standards/security_theft. 
our previous Reading Room and general Special Collections security. This article is in no way intended as an indictment of library staff or administrators. All institutions make tradeoffs to balance use and security, and no institution has unlimited funding. Existing measures allowed the library to determine what was taken, and camera footage of the theft was helpful for learning how the Porter Rockwell photograph was stolen and verifying that the suspect took it.

We should also note that the library has conducted a thorough evaluation of security and that many of the shortcomings we note below no longer exist. We applaud library administrators for their decisiveness in implementing enhanced security measures. In the following section, we quote from a section of the ACRL/RBMS Guidelines Regarding Security and Theft in Special Collections and then note what we were doing prior to the thefts. The purpose of this section is to highlight what went wrong so that other institutions can evaluate their own security measures for similar problems.

- "A secure reading room where researchers can be continuously monitored by staff trained in surveillance should be identified as the only area in which material may be used." ${ }^{26}$

The student employees we rely on are not trained in surveillance or to continuously monitor patrons. Additionally, full-time staff and faculty are not expected to assist in actively monitoring the reading room, especially after normal work hours.

- "Records should also be kept of projects researchers are working on and of collections they will be using." ${ }^{27}$

While we keep detailed records on researchers and the collections they use, we did not require them to tell us what they are working on.

- "Staff should observe researchers at all times and not allow them to work unobserved behind bookcases, book trucks, stacks of books, or any other obstacles... staff should check the condition, content, and completeness of each item before circulating it and when it is returned after use." ${ }^{28}$

One potential solution is to train student employees to help patrons set up their research space in a way that facilitates observation of their behavior. Student employees should also be trained to check the condition of requested materials before

26. "ACRL/RBMS Guidelines Regarding Security and Theft in Special Collections."

27. "ACRL/RBMS Guidelines Regarding Security and Theft in Special Collections."

28. "ACRL/RBMS Guidelines Regarding Security and Theft in Special Collections." 
and after patrons use them. Table/desk locations should not allow researchers to sit with their backs toward staff observation areas.

From our personal and anecdotal observations of interactions between student employees, we found that new student employees were too often left unsupervised, especially during evening shifts when only a single curator is on site, and on Saturdays when no curator was available. The only student employees with time to watch the reading room were the least experienced one, as more experienced students took on additional tasks and responsibilities over time, distracting from their role in monitoring the reading room. We would suggest that employees need to be trained to take an active role in checking rare books and manuscripts back in and out, and to monitor the reading room more actively by walking around a few times an hour and taking a few minutes to observe how patrons are using materials.

- "Staff members must be aware of their legal ability to stop thefts without infringing on the rights of suspects." ${ }^{29}$

Neither full-time employees nor part-time student employees receive training from the BYU Police Department on how to recognize and stop a theft in progress within the context of state law. Having access to documents explaining how to respond to suspected or known theft under Utah law and possibly an online training module, if executed well, might shore up this weakness.

- "A recent theft or act of vandalism may give an indication of a building area, subject, or type of material that will be the target of future theft or mutilation. If appropriate, transfer materials related to those already stolen or mutilated to a more secure area. The theft or mutilation of printed books or manuscripts may indicate that other genres of materials containing similar subject matter will become the targets of thieves and vandals." ${ }^{30}$

In the context of the thefts BYU experienced, this is equally applicable to the circulating open stacks and special collections. Over time, as the materials increased in value, we should have been proactive in moving books with notable Mormonrelated provenance out of circulation and into special collections. All libraries maintain collections of valuable materials; ensuring that they are kept in secure areas (whether on the shelf or in a vault) appropriate to their financial and cultural value is a vital aspect of librarianship and archival management. On the other hand, space is at a premium in every institution, and detailed subject knowledge and experience in purchasing rare materials are necessary skills to properly execute

29. "ACRL/RBMS Guidelines Regarding Security and Theft in Special Collections."

30. "ACRL/RBMS Guidelines Regarding Security and Theft in Special Collections." 
this task. Moreover, the task is a thankless one that will almost certainly never appear on an individual's Curriculum Vitae or resume. That being said, in piecemeal fashion, as employees and potentially library patrons recognize high-value items that ought to be better secured, institutions need to make a good-faith effort to protect irreplaceable materials.

Ideal security will not always be possible. Underfunded or minimally funded community archives and private collections may not be able to afford more than the most basic protections. Such institutions may consider transferring their most valuable records to a state university or historical society, though such a step is fraught with complexities and is no guarantee that another institution would even be willing to preserve them. Regardless, all who work with or own rare materials need to be aware of how thieves operate and take steps, such as visitor's logs and physical observation of patron use areas, to protect their collections.

Additionally, we should have had better surveillance cameras in place to monitor various areas of the library. While having full-building coverage is neither desirable, due to obvious privacy concerns, nor viable, due to the limits of technology, we could have monitored library spaces outside of special collections to a greater degree, since some areas were entirely lacking in surveillance of any kind.

Without access to significant funds for improving security, however, an archive or library will likely need to fall back on having employees or volunteers regularly take time to wander through areas of the library that cannot be monitored from a desk.

Ultimately, these types of security measures are important, but cameras are often useful only when theft has already occurred, and deducing when the theft took place may be impossible, rendering footage useless anyway. On the other hand, the deterrent value of visible cameras should also be considered. Alternatives such as regular employee walkthroughs will sometimes happen upon suspicious activity through serendipity, but the main value in such activities is to dissuade casual theft and mutilation of library materials. A determined thief with a plan will likely be able to avoid such measures. Camera footage does allow an institution to much more accurately determine what was taken and how, as long as the theft is detected before footage is deleted by regular processes. The best of both worlds is to have continuous monitoring of live feeds, though this will not be practical for most institutions.

- Materials that have not been completely cataloged or processed should be made available to researchers only if security is not compromised and additional precautions (such as more stringent supervision of use, a reduc- 
tion in the number of items dispensed at one time, and marking of items) are taken." ${ }^{31}$

Collections lacking a detailed inventory or folder item counts should receive additional precautions during patron use. We might even consider restricting access to Church-related collections that lack detailed finding aids, since such collections will almost certainly continue to be targeted by thieves, barring a complete collapse of the Mormon rare books and manuscripts market.

- 'The library should inform local booksellers of the institution's collecting area and establish a procedure for quickly informing them of any theft that has occurred in the repository." ${ }^{32}$

The library did not have an established procedure for informing local booksellers that a theft had occurred.

\section{Discussion}

To curb the theft of rare materials, libraries, archives, private collectors, and dealers in rare materials must be careful when making new acquisitions that the materials they are buying have not been stolen from cultural institutions, private organizations, or dealers. For decades, the profession has pushed to create computerized databases where stolen materials can be reported so that institutions and individuals can check before they purchase valuable items. ${ }^{33}$ This process has continued with various websites established to report and help track stolen materials. ${ }^{34}$

Establishing the provenance of manuscripts and rare books is the best method for determining if an item has been stolen, but full provenance will often prove impossible to establish. Moreover, many rare booksellers have a vested interest in keeping their sources private, since their long-term income depends on a steady flow of materials from established collectors and their families to new buyers. That having been said, many rare booksellers in our experience recognize the financial benefits of maintaining strong relationships with institutions and have actively approached institutions from which they suspect an item they have been offered, or even

\footnotetext{
31. "ACRL/RBMS Guidelines Regarding Security and Theft in Special Collections."

32. "ACRL/RBMS Guidelines Regarding Security and Theft in Special Collections."

33. John H. Jenkins, Rare Books and Manuscript Thefts: A Security System for Librarians, Booksellers, and Collectors (New York, NY: Antiquarian Booksellers' Association of America, 1982).

34. Examples include the International League of Antiquarian Booksellers' website https://stolenbook.org/, the Antiquarian Bookseller's Association of America's blog entitled The New Antiquarian found at https: / / www.abaa.org/blog/category/security, and Interpol's Stolen Works of Art Database's website https://www.interpol.int/Crimes/Cultural-heritage-crime/Stolen-Works-of-Art-Database.
} 
purchased already, may have been stolen. This was exactly what occurred with the materials that were stolen from BYU's Harold B. Lee Library.

Evaluating materials offered to determine if they are stolen property is a delicate matter.

First, consider the provenance and what you as the point person for the purchase know about the seller. While established rare books and manuscripts sellers generally hold to professional codes or standards, someone disposing of their family's books in a one-off sale has no such training or requirement. Attempting to determine if the seller is acting on their own with the legal right to do so or with approval from the rest of a family is difficult or sometimes impossible, but efforts to do so can save an institution from purchasing materials that will need to be returned to a family later, as well as from lawsuits alleging misconduct on the part of those who receive donations.

Buyers must be cautious of sellers who are applying inordinate amounts of pressure to buy their materials. Requiring a quick decision or refusing to allow the buyer time to inspect materials should raise red flags and cause the buyer to take a careful look at the situation and potentially walk away. Similarly, if the offer seems to be too good to be true, take the time to examine the offer more closely before committing to purchase the materials. A seller may be looking to be rid of incriminating evidence or really has no understanding of the value of the materials they are offering.

When working with sellers, it can be helpful to take into account their professional reputation. Often, those who have been in business for some time have established relationships of trust within their communities. Those who belong to professional organizations such as the Antiquarian Booksellers Association of America or the International League of Antiquarian Booksellers are required to meet relatively high standards of conduct, though enforcing those standards can be difficult. Additionally, many successful thieves have held positions of trust, which has aided them in their illegal activities. There is no need to look further than BYU's own backyard for examples. Mark Hofmann forged many documents in the early to mid-1980s, selling them as historic and rare documents. He quickly made a name for himself with his supposed finds and later murdered two people in an attempt to cover up his activities. ${ }^{35}$

Archivists purchasing collections need to know or at least be aware of institutions that specialize in materials related to the item. Consider also the size of the collection. A thief might be able to steal a letter from an archive, or a single photograph,

35. See, among other sources, Richard E. Turley, Jr., Victims: The LDS Church and the Mark Hofmann Case (Urbana, IL and Chicago, IL: University of Illinois Press, 1992). 
but it is more difficult to steal a whole file folder. As with rare books, reports of manuscript theft should be followed closely.

Before purchasing rare materials, they should be examined closely, as stolen materials may show signs of having been tampered with to conceal previous ownership. Attempts to bleach out stamps, erase pencil markings, and remove barcodes and checkout slips can indicate the materials have intentionally been altered. Rare booksellers will frequently leave provenance markings intact, such as checkout slips, though they have also been known to remove them if it will increase the value of the item. Keep in mind that withdrawn stamps can be faked to give the appearance that the materials are on the market legitimately, eliminating the difficult task of covering up institutional or private markings.

Traditionally, provenance is a valuable asset for determining the relevance and legitimacy of an item represented as having a particularly important owner or creator. Unfortunately, provenance can be misrepresented or even fabricated. ${ }^{36}$ Moreover, it is common for dealers to acquire single items from collectors who wish to remain private. Some rare document sellers will make an introduction to the source of the item if the seller's relationship to the archivist or their institution is strong. It is not uncommon for sellers to disclose provenance, and it should gently be suggested to sellers that approval for purchases will be more likely if detailed provenance is provided. Beyond these considerations, enter a few lines of an item into a search engine and see if the text has been transcribed somewhere, and if so, the archivist should attempt to contact the previous owner. Finally, avoid purchasing "clipped" signatures or signatures on single sheets of book paper without content or context.

It can be difficult knowing what to do if you are offered materials you suspect were stolen. Institutions should consider contacting local law enforcement to receive some measure of training on this topic. Some basic principles include:

1. Get basic contact information for any seller who approaches you-name, phone number, and email address are a good starting point.

2. Do not immediately accuse someone of having stolen the item they are offering you. Verify that the material was stolen by contacting the owner.

3. Do not attempt to hold on to an item that you suspect was stolen if the suspected thief demands its return. You are not law enforcement.

4. While you may ask to keep the item for a time for "further evaluation,"

36. Mark Hofmann, a noted forger and murderer active in the 1980s, planted a forged broadside, The Oath of a Freeman, in a New York bookstore "so that he could buy it, obtain a receipt with the title on it, and thereby establish a credible provenance for the Oath he would later print and try to sell." Turley, Victims, 318 . 
do not put yourself in harm's way. If they will not let you hold it for further evaluation, ask if you can take pictures of it for later reference.

5. Do not leave yourself open to accusations of misconduct by engaging in a game of tug-of-war over an item you are not certain was stolen.

Once a librarian or curator determines an item they are offered was stolen from another seller or institution, contact the injured party as soon as possible to verify. Additionally, many databases are available to see if an item has been reported stolen. ${ }^{37}$ Talk to the authorities and any legal counsel available to your institution immediately and be prepared to describe the appearance of the seller, details about the item they attempted to sell, and their contact information if possible.

\section{Conclusion}

In addition to following the principles found in the RBMS / ACRL Security guidelines, we recommend that institutions maintain a list of people and organizations to inform via phone or email in the event of a theft, including local booksellers, RBMS Security Committee, and the ABAA stolen items list. Librarians and archivists need to be at least passingly familiar with common methods used by thieves who target our rare books and manuscripts. The method used by the thief to cover his tracks was not new and has been reported in previous thefts. Yet, none of the staff in the library had been trained to look for such trickery. Reviewing common methods used for stealing rare materials on a regular basis would increase awareness when materials are being used or returned to the library.

At the time of this article's submission, the last book stolen from the library was returned by a local Orem bookseller, C.J. Peterson. Though we would never have known if he had decided to keep the books, his own conscience and appreciation for BYU led him to contact us once he noticed that the book had BYU markings on it. We applaud the willingness of all the booksellers who had acquired stolen materials from the thief discussed above to return them to us. None attempted to recoup their expenses from us or engaged in anything but the best behavior.

As libraries and archives evaluate their security and acquisitions policies and practices, we hope that this article will shed some light on areas that may prove to be of specific concern. Though many examples of theft response checklists can be found online, we have appended our own below as a potential model.

\footnotetext{
37. As mentioned above, examples include the International League of Antiquarian Booksellers' website https://stolen-book.org/, the Antiquarian Bookseller's Association of America's blog entitled The New Antiquarian found at https://www.abaa.org/blog/category/security, and Interpol's Stolen Works of Art Database's website https:/ / www.interpol.int/Crimes/Cultural-heritage-crime/Stolen-Works-ofArt-Database.
} 
114

RBM: A Journal of Rare Books, Manuscripts, and Cultural Heritage

APPENDIX A. Poetical Writings of Orson F. Whitney (1889)

1. Abraham O. Smoot/Orson F. Whitney association.

Crest

Q.

6.

Snook

clear Father:-

of Avery

Christmas $t$

hew Year!

$1859-90$.

$7 \%$

0. \%.

the

rp er

ley nolde Library

- rove

Il

hog

Y

ul

Fall 2020 | Volume 21, Number 2 
2. Title page markings:

a. Stolen book on the left, scan of the same book from Internet Archive on the right. Note that the lighting was poor for this photograph, but the essential points are clear-the title pages have identical smudges and stamping, and upon close examination one can see that the call number in the upper left-hand corner was erased from the stolen book.
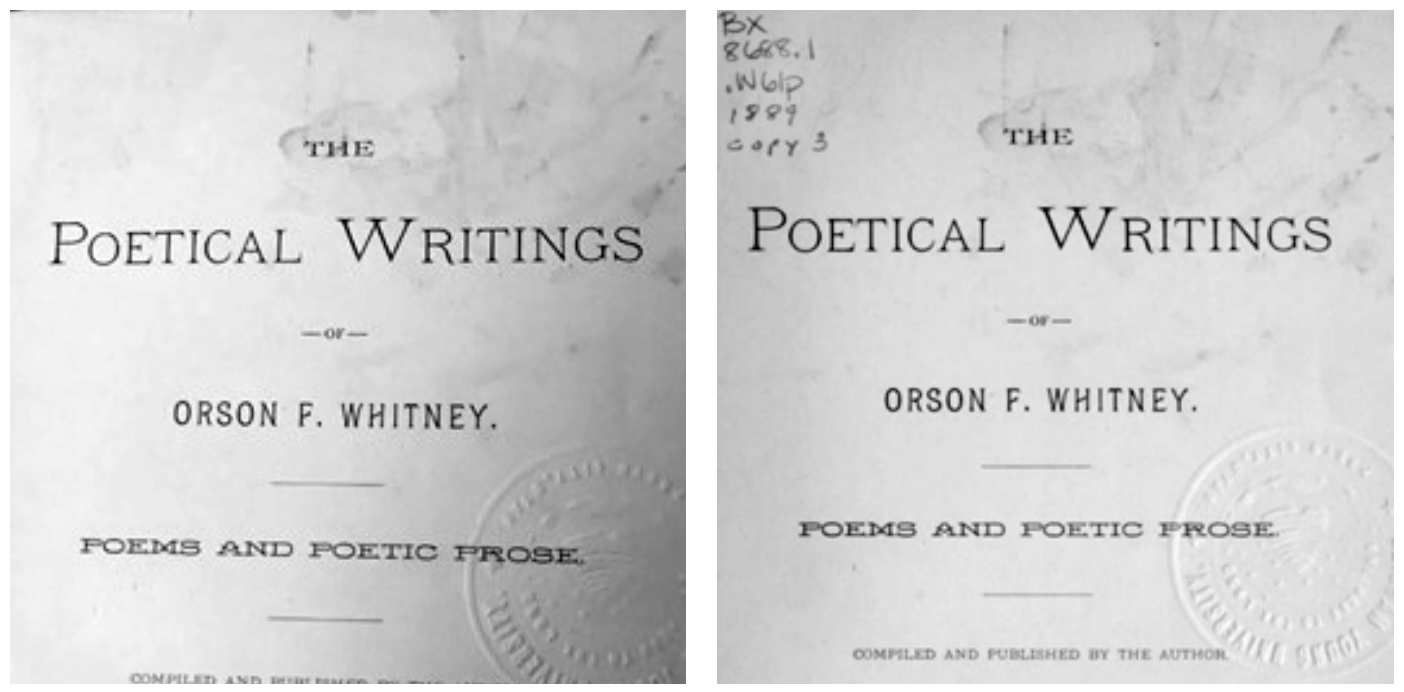

3. There is a light grey scuff mark on the righthand side of p. 179 in our book online. This same mark, which is unique to our copy, appears in the stolen book (left). The page was cropped when uploaded to Internet Archive, but the smudge remains visible.

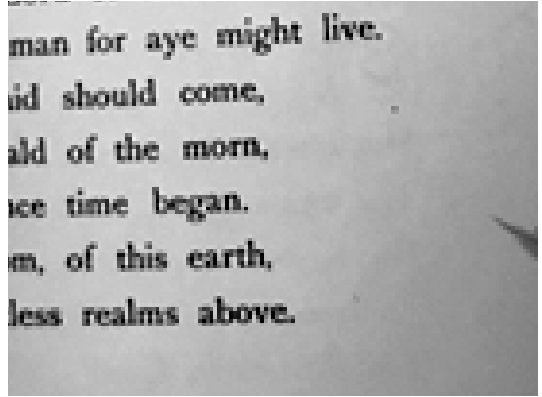

n for aye might live.

$$
\begin{aligned}
& \text { should come, } \\
& \text { of the morn, } \\
& \text { time began. } \\
& \text { of this earth, } \\
& \text { realms above. }
\end{aligned}
$$


4. Smudges on p. 58: Light black or grey smudges can be seen between the words "roses" and "droop," and a similar smudge is found on the word "flower" in the middle of the page. Stolen book on the top, our Internet Archive copy on the bottom.

\section{LOVE AND FRIENDSHIP.}

The stream of love is shallow and unclear,

And waves of trouble on its breast appear,

But friendship's tide is limpid as it flows,

And calmer, deeper, as it onward goes.

The fire of love is fickle and untrue,

And wanting fuel, pales its primal hue,

While friendship's glows with self-renewing light,

And warmest in the chilly glooms of night.

The rase of love, bereft of sunny ray,

Will droop and wither, fade and fall away;

In modest, sweet simplicity arrayed,

Tha flower of friendship blossoms in the shade.

Time's test on love may part the brittle chain,

Or on its links corrosive spots remain,

And wanting fuel, pales its primal hue,

While friendship's glows with self-renewing light,

And warmest in the chilly glooms of night.

The rose of love, bereft of sunny ray,

Will droop and wither, fade and fall away;

In modest, sweet simplicity arrayed,

The flower of friendship blossoms in the shade.

Time's test on love may part the brittle chain,

Or on its links corrosive spots remain, 
5. Barcode.

Image of the book from Internet Archive scan of BX 8688.1 W61p 1889 copy 3, barcode 31197004966138 , prior to removal by book thief:

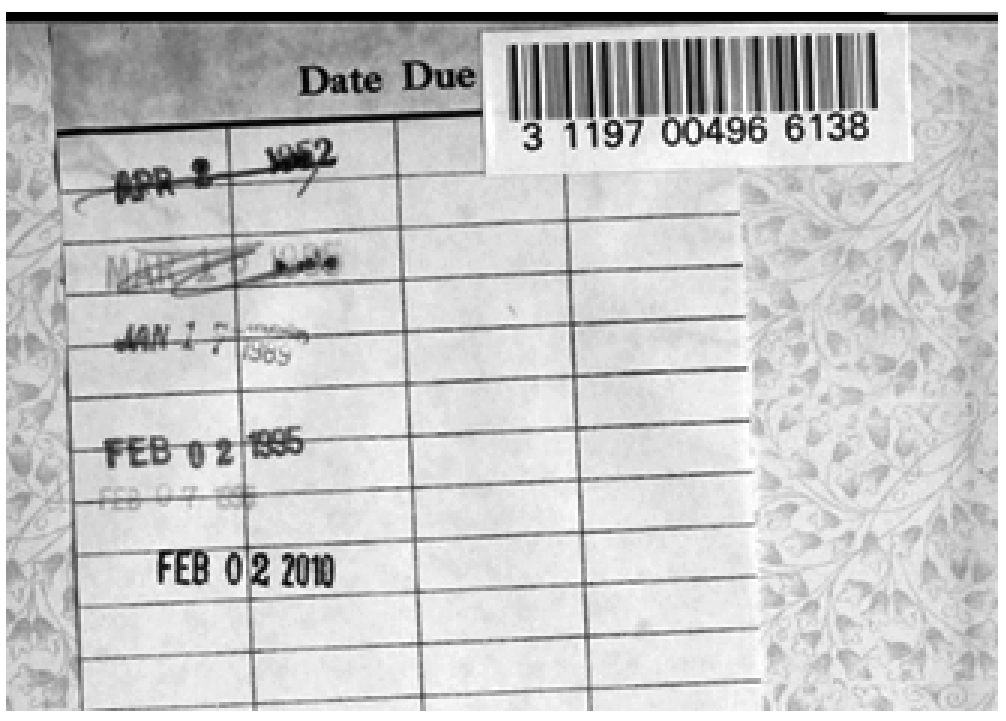

Space where barcode was removed:

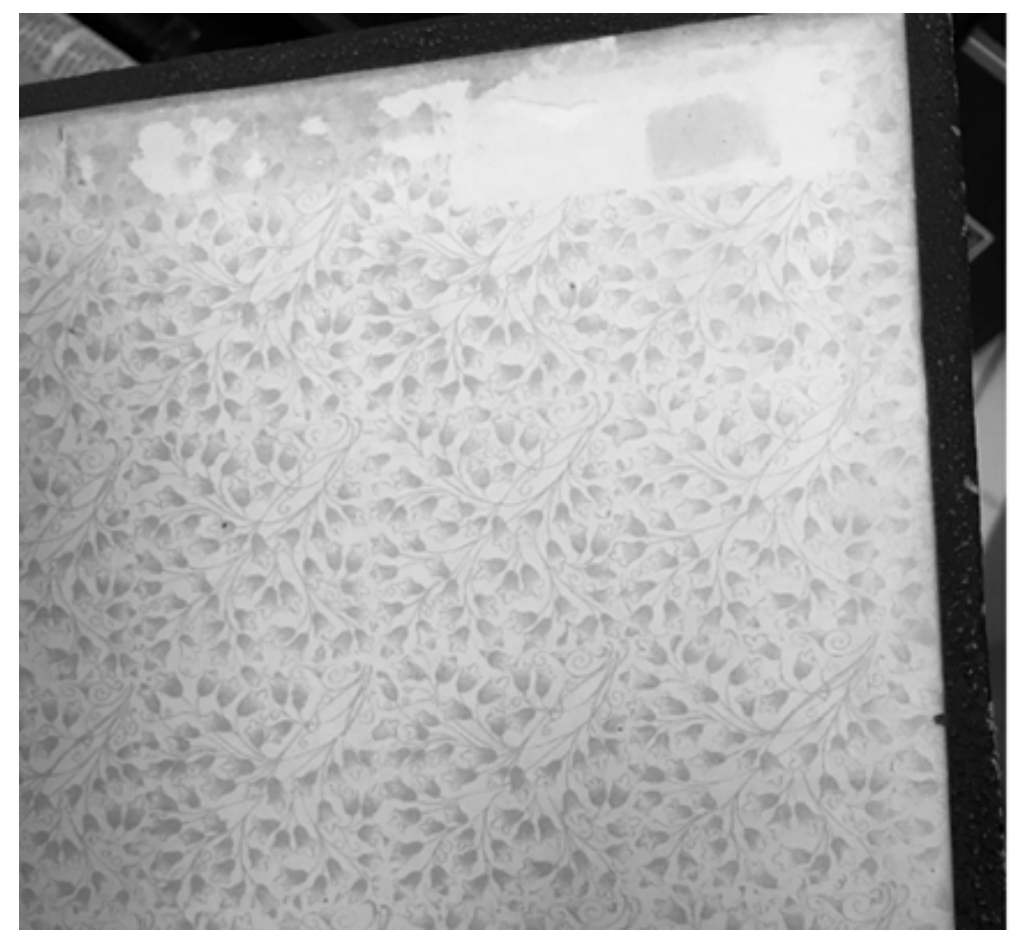




\section{APPENDIX B. Theft Follow-Up Worksheet}

1. What happened?

a. What was taken? Describe what was stolen, item by item, and attempt to estimate the market value of each item:

b. When did this happen? To the best of your knowledge, record each instance of theft related to the same suspect(s), including their name, date and time of the incident, and item stolen:

c. Do you have contact information for the thief? If their identity is unknown and no images exist, record their physical characteristics if possible:

d. How and when was the theft discovered?

e. Do you have images of the stolen material that could be used to identify them?

f. Do you have images of the suspect(s)?

g. Who is your institution's point person for working with police and the media regarding the theft(s)?

2. Who needs to know?

a. Local Police:

i. Name of contact:

b. Campus or Institutional Security Office (if applicable):

c. Insurer:

d. Legal Counsel:

e. Administrators and/or Board Members to notify:

i. Name of contact:

f. Employees responsible for security:

i. Name of contact:

3. Aftermath

a. Identify other immediate or long-term security risks to the collection.

b. What might be done to fully or partially mitigate these risks?

c. Who needs to take actions to mitigate risks?

d. Who needs to authorize actions to mitigate risks?

e. Are there any processes, policies, or procedures that need to be changed to increase collection security? Who will propose, authorize, and implement these changes?

f. Is additional funding needed to enhance security? Consider national, state, and local grants as well as fundraising activities to secure necessary funds. 